DE DE GRUYTER OPEN
Research Article

(C) 2017 Fayrouz Bencheikh and Neila Boulila Taktak. This is an open access article licensed under the Creative Commons Attribution-NonCommercial-NoDerivs License (http://creativecommons.org/licenses/by-nc-nd/3.0/).

\title{
The Effect of Political Connections on the Firm Performance in a Newly Democratised Country
}

Fayrouz Bencheikh

Higher Institute of Management of Gabès, Tunisia

Neila Boulila Taktak

Higher Institute of Management of Gabès, Tunisia

Doi: 10.1515/mjss-2017-0004

\begin{abstract}
The study of the effect of political connections on the Tunisian firm performance after the 2011 uprising is the focal point of the paper. First, by applying a multiple linear regression model, the results show that political connections are positively associated with the market firm performance. Thereafter, a difference in difference model is applied to separate the connected and non-connected firms. Such a method is most likely to determine the factors driving the market performance of politically connected firms. Hence, results reveal that leverage, age and equity holdings increase the market performance of politically connected firms.
\end{abstract}

Keyword: Firm performance, political connections, Tunisia

\section{Introduction}

Political connections are set up by the links between politicians and the business elites (Faccio 2006 and 2010). Actually, political connections bring about informal relationships favoring the appropriation of several advantages. The obtained advantages include an easier recourse to bank debts, tax exemptions and a larger market share. Other advantages lie in the search for a larger market share which can be achieved by a real monopolistic position, the advantages in the acquisition of concessions or licenses, and the acquisition of more prominent government contracts. Faccio (2006), in this respective, confirms the acquisition of these benefits from a sample of firms belonging to 47 countries.

Accordingly, it becomes reasonable to accept the fact that politically exposed firms can take advantage of their relationships either to maintain or improve their performance. As a result, a poorly performing and politically exposed firm can not easily justify its own position because political links, normally, should help to settle a certain number of problems. In this case, the reason for poor performance can only be due to the manager's lack of will or skill or to the additional costs required to maintain these relationships. Indeed, this impact has appealed the attention of several studies around the world. Among the ones who have found a positive effect we can cite (Faccio 2006 ; Goldman et al. 2009 ; Boubakri et al. 2012 ; Ang et al. 2013 ; Coulomb and Sangnier 2014 ; Ding et al. 2014 ; Ling et al. 2016 ; Rijkers et al. 2017). On the other hand, some others have found a negative effect such as Fisman 2001; Roberts 1990, Faccio and Parsley 2009, Faccio 2010; Saeed et al. 2015. The previous studies came up with mixed findings; therefore, it becomes increasingly important to scrutinize the benefits and costs of political connections so as to provide further 
explanations.

This article is aimed to study the impact of political connections on the performance of Tunisian firms. The particularity of this study lies in the choice of the context and the period of study. Indeed, the period of $2012-2015$ is characterized by the proliferation of a democratic atmosphere which came after a quarter-century of dictatorship. It is then important to check the impact of political connections on performance in these conditions. As a matter of fact, the study focuses on a sample of 49 Tunisian firms listed in the Tunis stock exchange. Among the selected firms, we identify those that are politically connected according to the definition of faccio (2006).

The obtained results reinforce the arguments in favor of a positive relationship between political connections and performance. Thus, the proliferation of a political atmosphere does not prevent the propensity of the firms which are politically connected to the acquisition of private profits.

This paper is organized as follows. Section 2 provides a literature review about the effect of political connections on the firm performance. Section 3 presents the sample and the variables studied. Section 4 focuses on the adopted methodology. Section 5 includes the results and discussion. The paper ends with a conclusion in section 6.

\section{Literature Review}

\subsection{The positive effect of political connections on the firm performance}

The resource-based theory predicts that politically connected firms can gain several advantages that allow them to realize competitive edges over their competitors (Barney 1991). This position improves performance as it has been proven by various studies. Goldman et al. (2009) are interested in the effect of political connections on the American firms listed in the stock-market. They come up with two main results. First, they point out that such links generate a value by anticipating the benefits that the politically connected person can raise in the future. Moreover, they show that these firms show a succession of abnormal returns after the appointment of a politically connected person in the board of directors. The authors state that these results are more strongly marked in large firms. The last result is consistent with Faccio (2006) who found that the value of a firm increases when there is a strong political connections. Similarly, after analyzing the price reaction of equities during the 2000 presidential election, Goldman et al. (2009) found that the American firms connected to the political party increase their value. Ang et al. (2013) show that political connections have a positive effect on the value of the firm by considering the case of Singapore. However, Ding et al. (2014) confirm this same positive effect by taking the case of China.

\subsection{The negative effect of political connections on the firm performance}

Indeed, political connections can have negative effects on the performance of the firm. This situation is made concrete when the objective of political connections is the appropriation of acquired private benefits in the form of rents at the expense of the performance of the firm. Shleifer and Vishny (1993) study the behavior of politically connected firms and point out that political connections are one of the main reasons for the firms' inefficiency. In addition, Shleifer and Vishny (1994) refer to the costs of the relationship between politicians and firms. In their analysis of the value obtained from political connections, they say that politicians themselves want to appropriate a part of this value in exchange for the connections that they provide; thus, the value of the firm will be improved only when the marginal benefits of political connections exceed their marginal costs. In this context, Fisman (2001) and Johnson and Mitton (2002) explain this fact through the politically exposed firms which focus on non-productive activities based on a rent situation that increases the burden and compensates for any other gain. De Soto (1989) argues that in Peru, bribes replace the taxes that must normally be paid by firms. Faccio and Parsley (2009) prove that the firms affected by political connections are decreasing their value after announcing the unexpected death of a politician. 


\section{Research Design}

\subsection{Data}

The sample comprises 49 Tunisian firms which are listed in the Stock Exchange of Tunis. The studied sectors are industry, food industry, trade, transport, tourism and communication. The banking, insurance, leasing and investment and the real estate sectors are excluded because of their different financial status. The study period spans over 4 years from 2012 to 2015.

Among the firms in the sample, we identify those that are politically connected. To do this, we refer to the definition proposed by Faccio (2006). According to the author, a firm is considered politically connected if one of the managers or shareholders is a member of parliament, a minister, or is closely related to a politician or a political party.

In fact, any firm that has, at the level of its ownership structure or board of directors, a minister, a person belonging to a political party, a member or a deputy of parliament or any person with political connections is considered to be politically connected.

\subsection{Variable definitions}

\subsubsection{Firm performance}

The firm performance is measured by the Tobin's $Q$. The market measure of the firm received a broad support in the previous literature (Wernerfelt and Montgomery 1988). The Tobin's $Q$ is constructed as the ratio of the market value of equity plus the book value of the total debts divided by the book value of the total assets.

\subsubsection{Political connections}

Most of the studies dealing with politically connected firms measure political connections by a dummy variable (Faccio 2006, Saeed et al. 2015). Also, the variable political connections (PC) takes the value 1 if at least a majority shareholder or a top executive member is politically connected and 0 otherwise.

Table 1: Variable definitions

\begin{tabular}{|c|c|}
\hline Variables & Definitions \\
\hline Tobin's Q & $\begin{array}{l}\text { The ratio of the market value of equity plus the book value of total debts divided by } \\
\text { the book value of total assets. }\end{array}$ \\
\hline $\begin{array}{l}\text { Political } \\
\text { connections (PC) }\end{array}$ & $\begin{array}{l}\text { Dummy variable that equal } 1 \text { if at least one of the shareholders or managers is a } \\
\text { member of parliament, a minister, or is closely linked to a politician or a political } \\
\text { party. }\end{array}$ \\
\hline $\begin{array}{l}\text { Leverage } \\
\text { (LEVERAGE) }\end{array}$ & The ratio of total debt to total assets \\
\hline Size (SIZE) & The natural logarithm of the total assets. \\
\hline Equity (EQUITY) & The ratio of equity to total assets. \\
\hline Age (AGE) & The natural logarithm of the firm age \\
\hline
\end{tabular}

\subsection{Estimation Models}

The aim of this research is to determine the effect of political connections on the Tunisian firm performance. The models are estimated by the generalized least squares (GLS) to raise the matter of auto-correlation error and heteroscedasticity. The standard errors are clustered at the firm and years levels. First, we estimate the following panel regression model:

Tobin's $Q_{i t}=\beta_{0}+\beta_{1}$ PC $_{i t}+\beta_{2}$ SIZE $_{i t}+\beta_{3}$ LEVERAGE $_{i t}+\beta_{4}$ EQUITY $_{i t}+\beta_{5} A_{G} E_{i t}+\delta_{t}+u_{i}+\varepsilon_{i t}$

Subsequently, a difference-in-difference model has been applied. The objective is to distinguish between two groups of firms. The group of interest is made up of the politically 
connected firms. The control group is composed of the non-connected firms. This method allows determining the factors driving the market performance of politically connected firms. The estimation model is the following:

Tobin's $Q_{i t}=\beta_{0}+\beta_{2}$ SIZE $_{i t}{ }^{*} P C_{i t}+\beta_{3}$ LEVERAGE $_{i t}{ }^{*} P C_{i t}+\beta_{4} E$ UUITY $_{i t}{ }^{*} P C_{i t}+\beta_{5} A E_{i t}{ }^{*} P C_{i t}+\delta_{t}+u_{i}+\varepsilon_{i t}$

Where, Tobin's $Q$ is the ratio of the firm's total market value to the total assets. $P C$ is a dummy variable which is equal to 1 if the firm is politically connected. SIZE is the natural logarithm of the total assets. LEVERAGE is the ratio of the total debt to equity. EQUITY is the ratio of the equity to the total assets. AGE is the natural logarithm of age. $\delta_{t}$ is the time fixed effect. $u_{i}$ is the individual fixed effect. $\varepsilon_{\text {it }}$ is an error term.

\section{Summary Statistics}

Table 2 presents the descriptive statistics for the whole sample. The average Tobin's $Q$ is 1.413 . This result shows that the firm-market value exceeds the book value and confirms the ability of the market value to identify the differences in systematic risks, temporary disequilibrium effects and potential future growth (Saeed et al. 2015). Similarly, they put emphasis on the limits of the accounting method. Furthermore, almost $27 \%$ of the firms are politically connected. The politically connected people are members of parliament, ministers, or persons who are closely related to a politician or a political party. The political connections are determined either through a participation in the ownership structure or through a membership in the board of directors.

Table 2: Summary statistics

\begin{tabular}{lccccc}
\hline Variables & $\mathbf{N}$ & Mean & Std.dev & Min & Max \\
\hline Tobin's Q & 147 & 1.413 & 0.972 & 0.068 & 1.875 \\
SIZE & 147 & 4.317 & 0.526 & 3.224 & 5.656 \\
LEVERAGE & 147 & 0.223 & 0.205 & 0 & 0.937 \\
EQUITY & 147 & 0.430 & 0.389 & 0 & 0.9484 \\
AGE & 147 & 3.407 & 0.632 & 1.386 & 4.489 \\
\hline Summary statistics for binary variable & Value & \multicolumn{3}{c}{ Frequency } \\
\hline Variable & 0 & \multicolumn{3}{c}{0.735} \\
\hline PC & 1 & 0.265 \\
\hline
\end{tabular}

The descriptive analysis is carried out through a comparison between two sub-samples made up of connected and non-connected firms. The results are presented in table 3 . The politically connected firms tend to outperform their peers. This performance is explained by a higher leverage, a larger size and seniority. However, these findings are statistically insignificant.

Table 3: Comparison between connected and non-connected firms

\begin{tabular}{lcccc}
\hline VARIABLE & $\begin{array}{c}\text { Non-connected firms } \\
(\mathbf{A})\end{array}$ & $\begin{array}{c}\text { Connectedted firms } \\
(\mathbf{B})\end{array}$ & $\begin{array}{c}\text { Difference } \\
(\mathbf{A}-\mathbf{B})\end{array}$ & \begin{tabular}{c} 
t-value \\
\hline Tobin's Q
\end{tabular} \\
\hline LEVERAGE & 54.265 & 1.561 & -0.296 & -1.001 \\
SIZE & 18.260 & 62.211 & -7.27 & -0.996 \\
EQUITY & 44.918 & 18.474 & -0.213 & -0.904 \\
AGE & 3.342 & 37.788 & 7.130 & 0.984 \\
\hline
\end{tabular}

The Pearson correlation matrix presented above indicates the absence of any correlation problem between the explanatory variables. 
Table 4: Correlation matrix

\begin{tabular}{lccccc}
\hline & PC & SIZE & LEVERAGE & EQUITY & AGE \\
\hline PC & 1 & & & & \\
SIZE & 0.0749 & 1 & & & \\
LEVERAGE & -0.1316 & 0.1345 & 1 & & \\
EQUITY & -0.0811 & $-0.1757^{*}$ & $-0.2653^{*}$ & 1 & \\
AGE & $0.1722^{*}$ & -0.0021 & -0.0469 & -0.0356 & 1 \\
\hline
\end{tabular}

* The coefficients are significant at an error threshold of $10 \%$

\section{Results and Discussions}

\subsection{The effect of political connections on the firm performance}

The regression results shown in Table (5) highlight the effect of political connections on performance. The coefficients associated with the political connections variable are positive and statistically significant. The positive association between performance and political connections has been proved by Ang et al. 2013; Goldman et al. 2009; Coulomb and Sangnier 2014; Ding et al. 2014 and $\mathrm{Li}$ et al. 2008. Similarly, these results are consistent with the theoretical predictions. According to the resource-based theory, political connections offer advantages allowing firms to perform better than their competitors. Also, the politically connected firms increase their performance through their market value which can be explained by the optimistic and confident perception of the investors vis-à-vis these firms.

Table 5: The effect of political connections on the firm performance

\begin{tabular}{|c|c|c|c|}
\hline VARIABLES & $\begin{array}{l}\text { (1) } \\
\text { GLS }\end{array}$ & $\begin{array}{c}(2) \\
\text { Clustred }\end{array}$ & $\begin{array}{c}\text { (3) } \\
\text { Clustred }\end{array}$ \\
\hline PC & $\begin{array}{l}0.210^{*} \\
(0.177)\end{array}$ & $\begin{array}{c}0.255^{*} \\
(0.179)\end{array}$ & $\begin{array}{c}0.0676 \\
(0.0878)\end{array}$ \\
\hline LEVERAGE & $\begin{array}{c}0.123^{* *} \\
(0.0623)\end{array}$ & $\begin{array}{c}0.117^{*} \\
(0.0625)\end{array}$ & $\begin{array}{c}0.0733^{\star * \star} \\
(0.0199)\end{array}$ \\
\hline SIZE & $\begin{array}{c}-0.00892 \\
(0.0625)\end{array}$ & $\begin{array}{r}-0.00544 \\
(0.0622)\end{array}$ & $\begin{array}{c}-1.145^{* * *} \\
(0.184)\end{array}$ \\
\hline EQUITY & $\begin{array}{c}0.129^{* *} \\
(0.0625)\end{array}$ & $\begin{array}{c}0.123^{* *} \\
(0.0626)\end{array}$ & $\begin{array}{c}0.0700^{\star * *} \\
(0.0202)\end{array}$ \\
\hline AGE & $\begin{array}{c}-0.00325 \\
(0.123)\end{array}$ & $\begin{array}{c}0.00132 \\
(0.123)\end{array}$ & $\begin{array}{c}0.00964 \\
(0.258)\end{array}$ \\
\hline Constant & $\begin{array}{c}-1.073^{*} \\
(6.180)\end{array}$ & $\begin{array}{l}-1.011 \\
(6.197)\end{array}$ & $\begin{array}{c}1.545^{\star * *} \\
(3.732)\end{array}$ \\
\hline $\begin{array}{l}\text { Firm FE } \\
\text { Year FE }\end{array}$ & & YES & YES \\
\hline
\end{tabular}

\subsection{The factors driving politically connected firm performance}

In order to study the determining factors of the performance of politically connected firms, we distinguish the connected and non-connected firms. The results are presented in Table (6). Leverage has a positive and significant relationship with performance. The use of debt is one of the factors that can improve the performance of these firms. Then, size is negatively and significantly associated with performance. The size of the firm does not seem to be of great importance in the performance of politically connected firms. In contrast, age is positively and significantly related to performance. This means that the oldest firms with political connections are among the most 
successful ones. The equity ratio is positively and significantly associated with the firm performance. Thus, equity holdings address the agency problem and enhance the firm market performance.

Table 6: The determinants of the politically connected firm performance

\begin{tabular}{|c|c|c|c|}
\hline VARIABLES & $\begin{array}{l}\text { (1) } \\
\text { GLS }\end{array}$ & $\begin{array}{c}\mathbf{2}) \\
\text { Clustred }\end{array}$ & $\begin{array}{c}(3) \\
\text { Clustred }\end{array}$ \\
\hline \multicolumn{4}{|c|}{ Connected firms } \\
\hline LEVERAGE & $\begin{array}{c}0.149^{* *} \\
(0.0645)\end{array}$ & $\begin{array}{c}0.143^{\star \star} \\
(0.0644)\end{array}$ & $\begin{array}{c}0.0429^{*} \\
(0.0239)\end{array}$ \\
\hline SIZE & $\begin{array}{l}-0.106 \\
(0.130)\end{array}$ & $\begin{array}{c}-0.0920 \\
(0.130)\end{array}$ & $\begin{array}{c}-0.999^{* * *} \\
(0.193)\end{array}$ \\
\hline EQUITY & $\begin{array}{c}0.148^{* *} \\
(0.0645)\end{array}$ & $\begin{array}{c}0.142^{* *} \\
(0.0644)\end{array}$ & $\begin{array}{c}0.0386 \\
(0.0244)\end{array}$ \\
\hline AGE & $\begin{array}{l}0.427^{*} \\
(0.230)\end{array}$ & $\begin{array}{l}0.417^{*} \\
(0.228)\end{array}$ & $\begin{array}{l}0.0412 \\
(0.309)\end{array}$ \\
\hline \multicolumn{4}{|c|}{ Unconnected firms } \\
\hline LEVERAGE & $\begin{array}{c}0.132^{* *} \\
(0.0596)\end{array}$ & $\begin{array}{c}0.127^{\star *} \\
(0.0597)\end{array}$ & $\begin{array}{c}0.0733^{* * *} \\
(0.0196)\end{array}$ \\
\hline SIZE & $\begin{array}{c}0.0506 \\
(0.0679)\end{array}$ & $\begin{array}{c}0.0525 \\
(0.0675)\end{array}$ & $\begin{array}{c}-1.147^{* * *} \\
(0.181)\end{array}$ \\
\hline EQUITY & $\begin{array}{c}0.144^{* *} \\
(0.0599)\end{array}$ & $\begin{array}{c}0.139^{* *} \\
(0.0599)\end{array}$ & $\begin{array}{c}0.0701^{* * *} \\
(0.0199)\end{array}$ \\
\hline AGE & $\begin{array}{l}-0.117 \\
(0.137)\end{array}$ & $\begin{array}{l}-0.106 \\
(0.137)\end{array}$ & $\begin{array}{c}-0.0658 \\
(0.261)\end{array}$ \\
\hline Constant & $\begin{array}{c}-1.261^{* *} \\
(5.921)\end{array}$ & $\begin{array}{c}-1.203^{* *} \\
(5.930)\end{array}$ & $\begin{array}{l}1.589^{* * *} \\
(3.676)\end{array}$ \\
\hline $\begin{array}{l}\text { Firm FE } \\
\text { Year FE }\end{array}$ & & YES & YES \\
\hline
\end{tabular}

\section{Conclusion}

Political connections are then an asset as far these firms benefit from many advantages. Thus, there is a consensus in the earlier literature regarding the preferential access to debt, tax exemptions and the acquisition of a larger market share. However, the effect of political connections on performance is not so certain because it is difficult to arbitrate between the costs and the benefits of political connections. This article is in line with this research to check the effect of political connections on the performance of Tunisian firms. The period of study began after the revolution which allowed us to test this effect in a democratic political environment. The obtained results show that political connections are an asset for performance. This confirms that the political links provide access to privileges regardless of the political atmosphere. As it is a market measure, it is also possible to confirm that investors place their trust in these firms. Similarly, our results allow us to conclude that the determinants of the performance of politically connected firms are mainly debt, seniority and equity holdings.

Since the revolution, Tunisia has not stopped improving its democratic course and its fight against corruption in its different forms. The topic of politically connected firms remains current to check the impact of the various reforms on the performance of these firms.

\section{References}

Ang, J. S, David, K. D., \& Tiong, Y. T. (2013). Political Connection and Firm Value. Asian Development Bank and Asian Development Bank Institute, 30, No. 2, 131-166. 
Barney, J. B. (1991). Firm resources and sustained competitive advantage. Journal of Management, 17 (1): 99 120.

Boubakri, N., Cosset, J.-C., \& Saffar. W. (2012). The impact of political connections on firms' operating performance and financing decisions. Journal of Financial Research, 35 (3): 397-423.

Coulomb, R., \& Sangnier, M. (2014). The Impact of Political Majorities on Firm Value: Do Electoral Promises or Friendship Connections Matter? Journal of Public Economics, 115, 158-170.

De Soto, H. (1989). The other path: The invisible revolution in the third worlds. Harper and Row Publishers, New York.

Ding, S., Jia, C., Wu, Z., \& Zhang, X. (2014). Executive political connections and firm performance: comparative evidence from privately-controlled and state-owned enterprises. International Review of Financial Analysis, vol. 36, pp. 153-67

Faccio, M., \& Parsley, D. (2009). Sudden Deaths: Taking Stock of Geographic Ties. Journal of Financial and Quantitative Analysis, 44, 683-718.

Faccio, M. (2006). Politically connected firm. American Economic Review, 96, 69-86.

Faccio, M. (2010). Difference between politically connected and non-connected firms: a cross country analysis. Financial Management, 39, 5-27.

Fisman, R. (2001). Estimating the value of political connections. American Economic Review, 91, 1095-1102.

Goldman, E., Rocholl, J., \& So, J. (2009). Do Political Connected Boards Affect Firm Value? Review of Financial Studies, 22, 2331-2360.

Johnson, S., \& Mitton, T. (2003). Cronyism and Capital Controls: Evidence from Malaysia. Journal of Financial Economics, 67(2), 351-82.

Li, H., Meng, L., Wang, Q., \& Zhou, L. (2008). Political connections, financing and firm performance: Evidence from Chinese private firms. Journal of Development Economics, 87, 283-299.

Ling, L., Zhou, X., Liang, Q., Song, P., \& Zeng, H. (2016). Political connections, overinvestments and firm performance: Evidence from Chinese listed real estate firms. Finance Research Letters. 1-6

Rijkers, B., Freund, C., \& Nucifora, A. (2017). All in the family: State capture in Tunisia. Journal of development economics, 124, 41-59.

Roberts, B. (1990). A Dead Senator Tells No Lies: Seniority and the Distribution of Federal Benefits. American Journal of Political Science, 34:31-58.

Saeed, A., Belghitar, Y., \& Clark, E. (2015). Do Political Connections Affect Firm Performance? Evidence from a Developing Country. Emerging Markets Finance and Trade, Vol. 52, Iss. 8, 1876-1891.

Shleifer, A., \& Vishny, R. (1993). Corruption. Quarterly Journal of Economics, 108 (3), 599-617.

Shleifer, A., \& Vishny, R. (1994). Politicians and firms. Quarterly Journal of Economics, 109 (4), 995-1025.

Wernerfelt, B., \& Montgomery, C. (1988). Tobin's Q and the importance of focus in firm performance. American Economic Review, r78 (1): 246-50. 